creating for him an atmosphere of study and character congenial to all and not inimical to the best interests of the society as a whole.

During the session, the first annual meeting of the National Institute of Sciences of India was held under the presidency of Sir Lewis Fermor, who took as the subject of his address "Methods used in the Correlation of Archaean Rocks". During the meeting it was announced that Prof. N. Bohr, Prof. A. Einstein, Sir Thomas Holland, Sir Frederick Gowland Hopkins, Sir Guy Marshall, Lord Rutherford of Nelson and Sir Charles Sherrington had become the first honorary fellows of the Institute.

At the annual meeting of the General Committee of the Indian Science Co gress Association, it was unanimously resolved to celebrate the silver jubileo of the Science Congres in January 1938 by inviting a deputation of scientific workers from the British Association and elsewhere to join in the meeting. Should this materialise, it is likely to be a landmark in the progress of science in India, and it is to be hoped that adequate financial support for this venture will be fortheoming.
W. D. WEST.

\title{
Science and Progress in Medicine
}

$\mathrm{I}^{\mathrm{N}}$ his presidential address to the twenty-third Indian Science Congress, held in Indore on January 2-8, Sir U. N. Brahmachari discussed the role of science in the recent progress of medicine. $\mathrm{He}$ said that no apology was needed for his choice of subject, since health is the foundation of all happiness; moreover, it is customary at the annual meetings for the president to refer to the recent advances in science, and as the progress as well as the future achievements of medicine depend to a great extent upon the help that she has had and may yet get from the other sciences, it was only suitable for him to give a review of the important contributions made by some of these other sciences in recent times towards the advancement of medicine. $\mathrm{He}$ also referred to some recent facts which may be of medical interest in the future.

The president then reviewed briefly recent contributions to knowledge made by the sciences of biochemistry and chemistry, physiology, physics and mathematics, psychology and genetics. $\mathrm{He}$ emphasised the importance of diet and referred to the statement that man's place in future history will depend in no small degree on the food he eats. He pointed out the gaps in our present knowledge of nutrition, such as our ignorance of what is the optimum intake of protein or fat. The minimum animal protein required for human consumption is an interesting subject for research, and the future may show that it may be influenced by climatic conditions, as well as by its relationship to other constituents of the diet. He suggested that certain obscure diseases of India should be investigated from the point of view of a mineral deficiency being the cause. He also referred to the work carried out by Tilak and his assistants on balanced diets for Indians : the dietary worked out by them includes, with the staple food grains in common use, soya beans, dried skimmed milk, rice polishings, fresh ground-nut cake and a preparation of sprouted seeds. Such dietaries may help to solve the problem of obtaining a reasonably good diet at a price the people can afford. Perhaps the science of nutrition will one day form part of the Department of Preventive Medicine of the State.

In the field of chemotherapy, Sir U. N. Brahmachari referred to his own and his colleagues' work on various aminoquinoline derivatives as antimalarial agents : they have found that the introduction of a hydroxy group increases the toxic action of the compounds on Paramecia, whilst that of a methoxy group abolishes their toxicity. He also mentioned some work on the hypnotic properties of extracts from the root of Rauwolfia Serpentina, and then briefly reviewed his investigations on the treatment of kala-azar with preparations of antimony, culminating in the discovery of urea stibamine, which to-day is pre-eminent in the treatment of this disease. Turning to the future, he envisaged the possibility that the isotopes of elements may play an important part in the maintenance of health and that they may vary in disease.

The contribution of physies to medical science has been partly in the domain of diagnosis and partly in that of treatment. For diagnosis come such instruments as the electro-card:ograph, the oscillograph, the ultra-violet microscope, the infra-red camera, the $\mathrm{X}$-ray tube and the spectrograph : for treatment, radium, light and electrotherapy and the $\mathrm{X}$-ray also, the latter having been used as well for crystal analysis. It is possible that $\mathrm{X}$-ray analysis may solve the problem of the order of the unit groups in a protein chain and so ultimately the structure of living matter. In fact, when we survey the immense development in the use of light waves, visible, ultrs. violet, X-ray and others in the investigation of structures and the treatment of disease, with their future potentialities, it may be said without conceit -truly we are beginning to see through a glass less darkly.

In his concluding remarks, Sir U. N. Brahmachari said that it is clear that the various sciences can be of great service to medicine, and that some of them have contributed very substantially to the relief of human suffering from disease. The science of medicine, which was once mostly limited to the study of disease, is now concerning herself with the study of health, by the increasing knowledge of nutrition, environment and eugenies. Life is adapting itself to many varied conditions and to considerable ex. tremes of environment. The capacity of man for adaptation has been achieved and can be maintained only by the possession of an almost changeless and constant medium, the blood, which acts as the direct environment of his most valuable possession, namely, the brain: surely the level at which the essential blood constituents are maintained may be called the constant of and for man, as fixed as other physical constants. Whether mankind advance or regress in the future, medicine and civilisation will advance and regress together for all time. 
The contribution of medicine to civilisation aided by the other sciences is great. A healthy body means a healthy mind, and such minds are less likely to cause internal or external strife. A day may be conceived when physical warfare will give place to warfare of the intellect. There will be no jealousy, and superiority or inferiority complexes will cease to exist. Man will live by making every part of the world healthy and habitable by im. proved methods of hygiene, thereby minimising the need for the control of population, the overgrowth of which has been considered to be, to a great extent, responsible for many wars of the past. Further, a day may come when the war mentality of individual statesmen, which may lead to war psychosis among the people, will be analysed and corrected by the psychiatrist and the psycho. logist.

Although the mechanism of life cannot be explained by the physies and chemistry of to-day, some of it may be explained by ultra-physicochemical laws that may be discovered in the future : yet even then one may not be able to say wherein enters the breath of life.

\section{British Industries Fair}

\section{SCIENTIFIC Exhibits}

$\mathrm{T}^{\mathrm{H}}$ HE British Industries Fair, 1936, which opened on February 17 , is not only the largest trade fair in the world, but it is also this year larger than it has ever been since it was first held in 1915 . Its object is to assemble before the greatest number of potential buyers, both from Great Britain and from overseas, the greatest possible concentration of British manufactures. Only goods manufactured or produced within the British Empire are permitted to be displayed, and no exhibitor may exhibit articles other than those of his own manufacture. Thus the Fair forms a visible microcosm, showing the variety, range and character of the goods manufactured or produced within the British Empire. It would, of course, be an impossible task to attempt to review the twenty-four miles of exhibits that constitute the combined stand frontage at London (including Olympia and the White City) and Birmingham. All that can usefully be attempted here is to direct attention to some features, selected somewhat arbitrarily, of the scientific exhibits at Olympia.

The most striking of these exhibits is that of the scientific instrument manufacturers, who have this year excelled their previous efforts to produce, by a combined or, rather, grouped exhibit, a massed impression of the great variety and range of their products. Truth to tell, it could be more impressive still, for, although most of the leading scientific instrument manufacturers are well represented, there se obvious and notable absentees. It must be allowed that this is in part due to the fact that many of the scientific exhibits, more particularly of electrical instruments used largely in industry, are to be seen at Birmingham, where they are more appropriately shown in the company of the engineering exhibits. Moreover, it is probable that some scientific instrument manufacturers, especially those whose products appeal more particularly to the research worker or to the educationist, deem the annual exhibition of the Physical Society a more suitable occasion for the display of their latest products. But the British Industries Fair is of the utmost national importance; it attracts visitors from almost every quarter of the world; and such visitors cannot help but take away with them a vivid, and perhaps lasting, impression of what British industry in general and, what is more to our present point, the British scientific instrument industry in particular, is like, regarded as a whole. It would be a pity if, from lack of support from some important firms in the industry, the impression should be gathered that the industry is less comprehensive, less varied in the range of its products and less remarkable in its achievements than in fact it is.

Nevertheless, those who have been responsible for the organisation of the grouped exhibit of scientific instruments at this Fair are to be warmly congratı1. lated on a notable and effective display. This year it occupies the record space of 5,840 square feet, the central and dominating feature being a scale model of the Eddystone Lighthouse which has been erected by Chance Brothers and Co., Ltd., of Birmingham. This firm shows, besides the usual mouldings for lenses and prisms, sample plates of various types of optical glass, including didymium glass, and a set of colour filters. In another case it is exhibiting specimens of laboratory ware, micro cover-glass and four shades of Crooke's glass.

Projection apparatus is well to the fore. Ross, Ltd. show the latest appliances for cine-photography, both for the silent and the sound film, as do Soho, Ltd. and Kalee, Ltd. A new feature in connexion with such apparatus is the exhibit of heat-resisting glass for the condensers, towards the satisfactory production of which a good deal of recent research has been directed. The firm of Charles Baker shows a new type of episcope, with a $f / 4$ anastigmat lens, the body incorporating a new system of ventilation, so that it remains relatively cool even when the apparatus is run for long periods. This firm also exhibits a new production, the 'universal lantern', again embodying a special system of cooling the body; and the 'ultra pack illuminator', which has been designed to take the place of the older form of vertical illuminator and hitherto has been made only abroad.

Barr and Stroud, Ltd. show a full range of varied types of binoculars. They reserve the exhibition of their navigational range finders for the Shipping Exhibition which is held later in the year. Their binoculars include the central focusing and separate focusing types, prismatic binoculars of extra wide angle, and a series of prismatic monoculars. They should be congratulated also on issuing, among their literature, an admirably lucid and concise little booklet, entitled "Choosing a Binocular", which will prove most useful to the potential purchaser, whatever make of binocular he may eventually buy. 